DOI https:// doi.org/10.32837/app.v0i65.308

УДК 323.2.328

\begin{abstract}
А. В. Пехник
ORCID ID: https://orcid.org/0000-0003-2534-7652 кандидат політичних наук, доцент, доцент каредри політичних теоріӥ Національного університету «Одеська юридична академія»
\end{abstract}

A. В. Кройтор ORCID ID: https://orcid.org/0000-0003-4652-7441 кандидат політичних наук, доцент каредри політичних теорій Національного університету «Одеська юридична академія»

\title{
РЕФОРМИ МІСЦЕВОГО САМОВРЯДУВАННЯ ТА ТЕРИТОРІАЛЬНОЇ ОРГАНІЗАЦЇ̈ ВЛАДИ В УКРАЇНІ В КОНТЕКСТІ СТАНОВЛЕННЯ ГРОМАДЯНСЬКОГО СУСПІЛЬСТВА
}

Демократичний транзит в Україні неможливий без демократизації та децентралізації системи державного управління. Реформування місцевого самоврядування на принципах субсидіарності є логічним процесом під час формування громадянського суспільства як основи демократичного транзиту, що може забезпечити оптимізацію системи публічного управління. В умовах демократизації та забезпечення сталого функціонування інститутів громадянського суспільства модернізація публічної влади має сприяти створенню клієнтоорієнтованої системи державного управління, що забезпечить ефективне надання послуг громадам і стане чинником підвищення їхньої соціальної, економічної і політичної активності.

Реформа місцевого самоврядування передусім повинна забезпечити створення раціональної, а отже, і ефективної, моделі регіональної організації влади на засадах децентралізації повноважень та відповідальності в розробленні й ухваленні управлінських рішень на місцях з урахуванням місцевих особливостей. Крім того, реформа має забезпечити формування економічно спроможних територіальних громад, що, безумовно, вплине на зміну регіональної політики. Також результатом реформування буде процес формування впливових місцевих еліт із середовища громадських активістів, місцевих політиків, які в боротьбі за право ухвалювати рішення в межах територіальних громад не будуть опиратися на «протежування» державних службовців чи представників регіональних еліт вищого рівня. Оскільки їхня успішність залежатиме від легітимності місцевого рівня, джерелом якої буде ефективність діяльності цих лідерів у межах територіальних громад. Поряд із політичними партіями виникатиме нове джерело ротації еліти та рекрутування політичних лідерів.

Варто зазначити, що децентралізація передбачає передачу прав з ухвалення рішень не органам державного управління на місцях, а органам, що не перебувають в ієрархічній підпорядкованості органам центральної влади. Такими органами і $є$ місцеві громади, які отримають широкі економічні права щодо ухвалення та реалізації управлінських рішень. А з іншого боку, децентралізація, як зауважувалось, забезпечить формування впливових еліт місцевого рівня, зокрема і політичних. Унаслідок цього місцеві вибори по всій державі отримують менш ідеологічний виборчий процес, а популізм та ідеологічне протистояння, характерне для виборчих парламентських, президентських кампаній, на рівні виборчих процесів місцевого рівня втратить першочергове значення.

С. Малаш вказує на те, що реформа місцевого самоврядування повинна була б цілковито завершитись у 2020 р. разом із переформатуванням територіальної організації влади. Перший етап реформи розпочався $з$ добровільного об'єднання громад (Малаш, 2017). Відповідно до ст. 3 Закону «Про добровільне об'єднання громад», суб'єктами добровільного об'єднання територіальних громад є суміжні територіальні громади сіл, селищ, міст. У Законі, зокрема, визначено три типи територіальних громад за суб'єктами об'єднання, а саме: 
1. Сільська - громада, центр яких село.

2. Селищна - центром громади є селище.

3. Міська - громада із центром у місті (Закон України «Про добровільне об'єднання територіальних громад», 2020).

Законом визначенні основні умови об'єднання територіальних громад, дотримання яких забезпечує ефективність діяльності новостворених об'єднань у майбутньому, зокрема, у ст. 4 даного Закону визначено такі вимоги, що мусять враховуватись під час утворення громад:

1) у складі об'єднаної територіальної громади не може існувати іншої територіальної громади, яка має свій представницький орган місцевого самоврядування;

2) територія об'єднаної територіальної громади має бути нерозривною, межі об'єднаної територіальної громади визначаються за зовнішніми межами юрисдикції рад територіальних громад, що об'єдналися;

3) об'єднана територіальна громада має бути розташована в межах території Автономної Республіки Крим, однієї області;

4) під час ухвалення рішень щодо добровільного об'єднання територіальних громад беруться до уваги історичні, природні, етнічні, культурні й інші чинники, що впливають на соціально-економічний розвиток об'єднаної територіальної громади;

5) якість та доступність публічних послуг, що надаються в об' єднаній територіальній громаді, не можуть бути нижчими, ніж до об'єднання;

6) об'єднання територіальних громад здійснюється відповідно до перспективних планів формування територій громад Автономної Республіки Крим, області (Закон України «Про добровільне об'єднання територіальних громад», 2020).

У ч. 2 даної статті регламентується визначення центру територіальної громади. Зокрема, адміністративним центром об'єднаної територіальної громади має бути населений пункт із розвинутою інфраструктурою та зручним щодо всіх меж громади географічним місцем розташуванням (Закон України «Про добровільне об'єднання територіальних громад», 2020).

Відповідно до підготовленого моніторингу процесу децентралізації влади та реформування місцевого самоврядування, Міністерством розвитку громад та територій України у січні 2020 р. створено 1029 об'єднаних територіальних громад (охоплено 71,4\% площі України) із 1441 затвердженої перспективним планом уряду, що охоплює 90,3\% території держави (Міністерство розвитку громад та територій України, 2020).

Процес утворення об'єднаних громад став досить затяжним та повільним у перший період і потребує активізації у 2020 р., щоби відповідати запланованим етапам реалізації реформи. Так, відповідно до даних моніторингу, у 2015 р. на добровільних засадах створено лише 159 об'єднаних громад, у 2016 р. створено нових 207 (загальна кількість - 366), 2017 р. ознаменувався створенням додаткових 299 громад (загальна кількість - 665), а у 2018 р. кількість об'єднаних територіальних громад збільшилась лише на 141 (загальна кількість становила 806). Зрештою, у 2019 р. загальна кількість об'єднаних територіальних громад становила 1029, якими об'єднано 4698 громад (Міністерство розвитку громад та територій України, 2020). Отже, необ'єднаними залишалися 6263 громади.

3 огляду на необхідність завершення об'єднання громад, Верховна Рада внесла зміни до Закону «Про добровільне об'єднання територіальних громад» для пришвидшення процесу ï утворення. Нині перспективні плани формування громад розробляються та подаються на затвердження Міністерству розвитку громад та територій обласними державними адміністраціями, а обласні ради втратили вплив на процес формування територіальних громад. Отже, процес добровільного об'єднання із 2020 р. перейшов в адміністративно-плановий.

Процес об'єднання громад засвідчив, що середня чисельність такої громади становить 11388 жителів. У межах громад проживає 11,7 млн. осіб, що становить 33,3\% від загальної кількості населення (Міністерство розвитку громад та територій України, 2020).

В умовах реформування місцевого самоврядування в Україні виник новий інститут представницької влади у громадах - староства. Відповідно до ст. $14^{-1}$ Закону «Про добровільне об'єднання територіальних громад», у селах, селищах, визначених за рішенням місцевої ради об'єднаної територіальної громади, крім ії адміністративного центру, обирається староста 
на строк повноважень місцевої ради. Староста - це посадова особа місцевого самоврядування, член виконавчого комітету ради об'єднаної територіальної громади за посадою, що виконує такі функції:

1) представляє інтереси жителів села, селища у виконавчих органах сільської, селищної, міської ради;

2) сприяє жителям села, селища в підготовці документів, що подаються до органів місцевого самоврядування;

3) бере участь у підготовці проєкту бюджету територіальної громади в частині фінансування програм, що реалізуються на території відповідного села, селища;

4) вносить пропозиції до виконавчого комітету сільської, селищної, міської ради з питань діяльності на території відповідного села, селища виконавчих органів сільської, селищної, міської ради, підприємств, установ, організацій комунальної форми власності та їх посадових осіб;

5) виконує інші обов' язки, визначені Положенням про старосту (Закон «Про добровільне об'єднання територіальних громад», 2020).

Відповідно до моніторингу Міністерства, загальна кількість створених староств станом на 10 січня 2020 р. становила 3207, з них обрано 800 (Міністерство розвитку громад та територій України, 2020).

Варто зазначити, що спроможні об'єднання громади активно перехопили ініціативу в економічно-господарському розвитку не лише своїх громад, алей й цілих господарських районів, що свідчить про певний успіх реформи і формування громадянського суспільства в межах місцевих громад. Зокрема, територіальними громадами були укладені 530 договорів муніципального співробітництва у сфері житлово-комунального господарства, благоустрою, пожежної безпеки, освіти, охорони здоров'я, соціального забезпечення, інші проекти співпраці (Міністерство розвитку громад та територій України, 2020).

Однією з перешкод на шляху швидкого й ефективного створення об'єднаних територіальних громад $є$ недосконалість законодавчого регулювання цього процесу. Так, В. Козіна зазначила, що «сьогодні понад 800 секторальних законів регулюють повноваження в окремих сферах господарювання, економіки органів місцевого самоврядування. Крім того, близько 200 повноважень передбачено в законах про місцеве самоврядування і про місцеві державні адміністрації. I дуже часто ці повноваження між собою не кореспондуються. Звідси - шалені правові колізії, незабезпеченість повноважень фінансовими ресурсами і так далі» (Децентралізація онлайн-обговорення, 2020).

Утворення спроможних територіальних громад, що стануть основою ефективної системи місцевого самоврядування, має забезпечити якість надання публічних послуг окремому громадянину - жителю громади, який матиме змогу обстоювати, захищати та реалізовувати свої права, інтереси в межах місцевої громади. Такі громадяни стануть активними учасниками господарського, соціально-політичного та культурного життя громади, оскільки усвідомлюватимуть свій вплив на процес ухвалення рішень у громаді і водночас вплив цих рішень на рівень власного життя. Саме так знизу буде забезпечений процес формування відповідальної, активної участі громадян у житті громади. А в межах політичної системи держави сформується громадянське суспільство, що зменшить неопатримоніальні практики в політичному житті країни.

Сучасна регіональна політика України має забезпечити структурні та якісні зміни в регіональному розвитку держави, водночас подолати відцентрові тенденції, забезпечити соціально-культурну, політичну, економічну та територіальну цілісність держави. А також регіональна політика повинна подолати наявну диспропорцію в розвитку регіонів, забезпечити однаково якісний рівень життя населення в усіх областях держави.

Натепер держава залишається основним розпорядником фінансових ресурсів, що надходять у регіони з метою стимулювання економічної діяльності на місцях та вирівнювання міжрегіональних диспропорцій.

Крім того, реформа повинна враховувати не лише існуючі процеси трансформації економічного розвитку в окремих регіонах держави та країни загалом, але й зміни економічної структури Європи як основного партнера України. Також варто усвідомлювати, що економічний розвиток держави залежить від сучасних геополітичних чинників, які у зв' язку з агресією 
Росії потребують переорієнтації вітчизняної економіки, пошуку альтернативних джерел постачання та нових ринків збуту конкурентоспроможної продукції місцевого виробництва.

Серед внутрішніх викликів у реформуванні регіональної політики варто означити такі, як:

- низька інтенсивність інтеграційних процесів під час формування внутрішнього ринку країни;

- небезпечні напрями в розвитку процесу розселення, пов'язані з катастрофічним зменшенням сільського населення та сільськогосподарським виробництвом кінцевого продукту, що призводить до подальшої деградації сіл та селищ;

- спад економічного виробництва та підвищення собівартості виробленої вітчизняної продукції, що зменшує ії конкурентність на ринку споживання;

- високий рівень імпортозаміщення;

- військовий конфлікти на сході держави, нестабільність урядів і неефективність їхньої політики, що не сприяє поліпшенню інвестиційного клімату;

- індустріальні регіони не мають різновекторної спеціалізації виробництва, водночас промислово-індустріальні регіони зазнають зниження індустріального виробництва, натомість аграрні зіткнулись із соціальною депривацією і подальшим відставанням у соціально-економічному розвитку від решти регіонів.

На думку Я. Жаліло, «очевидним є двосторонній взаємозв'язок між посиленням дієвості територіальних громад та ефективністю регіональної політики. Перше без другого може стати відверто деструктивним, а отже, розбудова сучасної регіональної політики - «ключ» до успішної децентралізації та адміністративно-територіального оновлення країни. Таким чином, децентралізацію слід розглядати як елемент, етап формування ефективної політики регіонального розвитку» (Жаліло, 2018).

Отже, децентралізація повинна забезпечити реальний перерозподіл владних повноважень і фінансових потоків на користь місцевого самоврядування, що забезпечить можливість органам місцевої влади розпоряджатися раціонально існуючим потенціалом для ефективного подолання місцевих проблем та забезпечення сталого розвитку. Крім того, децентралізація стає стимулом економічного зростання регіонів, а регіональні політичні еліти переорієнтовуються з боротьби за центральну владу на боротьбу за отримання та збереження влади на місцях, що залежить не від ідеологічних гасел, а від реальних господарських успіхів на місцях. Варто зазначити, що на це спрямована і реформа виборчої системи України.

Водночас зростання економічних можливостей і перспектив розвитку регіонів у межах упровадження децентралізації спонукатиме до постійної взаємодії регіонального та місцевого управління, що пов' язане з необхідністю реалізації регіональних програм і проєктів розвитку, залучення інвестицій, розбудови регіональної інфраструктури. Також регіональний рівень влади стає основним у забезпечені як міжрегіональної, так і вертикальної двонаправленої взаємодії «центр - регіон», «регіон - місцева влада» 3 питань регіонального планування розвитку.

Варто враховувати і те, що ефективність локальних процесів не завжди сприятиме ефективності регіональних через ризик загострення центрально-периферійних відносин та концентрування економічної активності переважно на рівні обласних центрів, великих і середніх міст, а також стагнацію територій із нижчим потенціалом розвитку, неможливість вирішення або консервації проблем, які потребують значних ресурсів. Тому державна регіональна політика в умовах реформи децентралізації має забезпечити регіональну конвергенцію, тобто зменшення міжрегіональних та внутрішньорегіональних дисбалансів. Проблема просторової нерівномірності розподілу економічної активності регіонів зберігає свою актуальність.

Ефективність регіональної політики залежить від двох складників, як-от:

- по-перше, державна підтримка розвитку депресивних регіонів, а отже, і визначення критеріїв депресивності, стратегії їх подальшого розвитку, стимулювання його з метою виходу з такого стану;

- по-друге, державна підтримка окремих об'єднаних територіальних громад, що внаслідок їх створення не мають достатніх ресурсів для нарощування економічного потенціалу. Розвиток депресивних регіонів та громад потребує фінансової підтримки держави та чітко визначеної системи державних дотацій. 
Подоланню проблем депресивних територій, зокрема Карпат, має сприяти Концепція розвитку гірських територій українських Карпат на 2019-2027 рр. У концепщії перелічено низку чинників, що зумовили депресивність вказаного регіону, передбачено заходи і шляхи їх подолання, серед них такі:

- формування конкурентної економіки гірських територій;

- скасування інфраструктурних обмежень, розбудова просторово збалансованої виробничої і соціальної інфраструктури;

- розвиток туристичного потенціалу;

- гарантування екологічної безпеки (Концепція розвитку, 2019).

Тому формування ефективної антидепресивної політики є невід'ємною складовою частиною сучасної державної регіональної політики, що потребує належного правового та фінансового забезпечення.

Без розбудови інвестиційної системи й інфраструктури регіонального розвитку на можливе ефективне здійснення реформи регіонального управління та місцевого самоврядування. 3 огляду на це була створена Агенція регіонального розвитку із широкою мережею обласних органів.

У 2016 р. уряд ухвалив Типове положення про Агенцію регіонального розвитку, згідно 3 яким кожний регіон має право створити неприбуткову небюджетну установу, діяльність якої спрямована на ефективне впровадження місцевою владою стратегії розвитку даної території згідно із затвердженим планом.

Основні функції Агенції, відповідно до затвердженого положення, такі:

«1) проведення аналізу соціально-економічної ситуації, проблем розвитку відповідного регіону, подання Верховній Раді Автономної Республіки Крим, обласним, Київській та Севастопольській міським радам, Раді міністрів Автономної Республіки Крим, обласним, Київській та Севастопольській міським держадміністраціям пропозицій щодо шляхів їх розв'язання;

2) вивчення досвіду інших держав щодо реалізації регіональної політики та підготовка пропозицій щодо використання позитивного досвіду в регіоні;

3) сприяння, у тому числі шляхом організації та проведення консультаційної роботи < ...>:

4) участь у:

- проведенні моніторингу стану виконання в регіоні завдань, визначених Державною стратегією регіонального розвитку, плану заходів з реалізації регіональної стратегії розвитку, програм і проєктів регіонального розвитку;

- розробленні пропозицій щодо правового регулювання питань регіонального розвитку;

5) інформування громадськості про діяльність Агенції, зокрема шляхом розміщення на своєму офіційному вебсайті відповідної інформації та в інший прийнятний спосіб» (Постанова, 2016).

Упровадження Державної стратегії регіонального розвитку має деякі недоліки, а саме:

- недовершеність системи показників реалізації стратегії через неможливість отримання прогнозованих показників;

- несформований порядок надання результатів моніторингу, зокрема через процедуру оприлюднення його результатів;

- неконтрольованість, не завжди відповідають пріоритетним цілям Державної стратегії регіонального розвитку;

- відсутність чітко визначеної відповідальності за провали в реалізації проєктів, передбачених Стратегією;

- незбалансованість термінів розробки Державної регіональної стратегії розвитку до 2027 р. та розробки регіональних стратегій. Цей процес відбувається паралельно, тому унеможливлюється всеохоплююче врахування регіональних проєктів розвитку в Державній стратегії (Державна стратегія, 2020).

Варто зазначити, що ефективність реалізації Державної стратегії регіонального розвитку залежатиме від урахування в ній особливостей регіональної ідентичності й ефективного поєднання галузевого, географічного й управлінського чинника регіональної політики. Крім того, з огляду на загальний процес демократизації, під час розроблення стратегії 
регіонального розвитку не варто ігнорувати гендерний принцип рівності, що забезпечить урахування інтересів усіх груп населення в різних сферах життя суспільства на регіональному рівні.

Важливим аспектом успішності реалізації Державної стратегії регіонального розвитку, як зазначає В. Негода, є смарт-спеціалізації регіонів, що передбачає визначення кожним регіоном у рамках своєї стратегії цілей та завдань, що направлені на розвиток видів економічної діяльності, які мають інноваційний потенціал з урахуванням конкурентних переваг регіону та сприяють трансформації секторів економіки в більш ефективні (Мінрегіон, 2020).

Державна стратегія мусить враховувати той факт, що сучасні міста є інтегруючим чинником економічного, соціального та культурного життя територій і окремих регіонів. Розвиток інноваційної діяльності, а отже, інвестицій у даному секторі повинен бути спрямований на міста як центри концентрації інноваційно-інтелектуальних видів економічної діяльності. Тому треба якомога раціоналізовано узгодити регіональний та місцевий компоненти регіональної політики, забезпечити їхню інтегрованість.

Інтеграція й інтеракція органів влади, приватного сектора та регіональної політики на загальнодержавному, регіональному та місцевому рівнях забезпечить ефективне поєднання наявних ресурсів інституційних можливостей органів влади трьох рівнів та бізнесу для реалізації економічних проєктів регіонального розвитку, що має бути враховано під час розроблення та реалізації стратегії регіонального розвитку.

Отже, інтеграційний підхід є вкрай важливим і для розроблення стратегії розвитку об'єднаних територіальних громад, адже забезпечить поєднання фінансових, матеріальних, управлінських, інноваційних ресурсів для вирішення проблем місцевого значення

Трансформація державної регіональної політики потребує:

- удосконалення нормативно-правової бази реалізації державної регіональної політики 3 метою забезпечення узгодженості базового законодавства регіональної політики та законодавчих актів у сфері інвестиційної діяльності, просторового планування, фінансового та ресурсного забезпечення, а також гармонізації існуючих і новоутворених інституцій та механізми державної підтримки регіонального розвитку;

- удосконалення фінансового забезпечення реалізації державної регіональної політики, щоби раціоналізувати використання коштів;

- поліпшення координації політики між різними рівнями державної, регіональної влади і місцевого самоврядування, забезпечення горизонтальних інтеграційних зв'язків усіх секторальних політик;

- удосконалення розроблення стратегій регіонального розвитку з урахуванням досвіду європейських держав у процесі визначення стратегічних цілей модернізації регіонів та їх галузей спеціалізації і розвитку нових з урахуванням ресурсного потенціалу територій.

Неабиякого значення набуває потреба врахування статусу міст у реалізації регіональної політики, а також створення сприятливих чинників розвитку економічної взаємодій на міжрегіональному рівні та рівні об'єднаних територіальних громад.

Варто вказати на те, що визначення стратегічних пріоритетів державного та регіонального розвитку з метою забезпечення сталого економічного розвитку потребує пошуку нових методів збільшення продуктивності використання природно-ресурсного, матеріально-технічного та людського потенціалів регіонів, а також стратегії подолання депресивності окремих регіонів, об'єднаних територіальних громад.

Реформування регіональної влади в Україні в умовах демократизації та розвитку громадянського суспільства потребує наявності чітко визначених індикаторів ефективності діяльності органів місцевого самоврядування у сфері ухвалення, упровадження рішень та надання необхідних послуг населенню.

\section{Лimepamypa:}

Державна стратегія регіонального розвитку на період до 2027 р. 2020. URL: https:/ oda.odessa.gov.ua/ statics/pages/files/5e37ef526fbf7.pdf.

Жаліло Я. Про принципи сучасної політики регіонального розвитку. 2018. URL: https://dt.ua/ macrolevel/pro-principi-suchasnoyi-politiki-regionalnogo-rozvitku-281358_.html. 
Про внесення змін до деяких законів України щодо визначення територій та адміністративних центрів територіальних громад : Закон України від 16 квітня 2020 р. Голос України. 2020. № 79.

Про добровільне об'єднання територіальних громад : Закон України. $2020 . \quad$ URL: https://zakon.rada.gov.ua/laws/show/157-19.

Концепція розвитку гірських територій українських Карпат на 2019-2027 pp. 2019. URL: https:/ / zakon.rada.gov.ua/laws/show/232-2019-\%D1\%80.

Малаш С. Проблематика взаємовідносин між органами виконавчої влади та громадськістю. Державне управління: теорія та розвиток. 2017. № 9. С. 21-27.

Моніторинг процесу децентралізації влади та реформування місцевого самоврядування станом на 10 січня 2020 р. / Міністерство розвитку громад та територій України. 2020. URL: https:/ / decentralization.gov.ua/uploads/library/file/526/10.01.2020.pdf.

Смарт-спеціалізація є обов' язковою у системі стратегічного планування регіонального розвитку / Мінрегіон. 2020. URL: https:/ / decentralization.gov.ua/news/10590.

Про затвердження Типового положення про агенцію регіонального розвитку : постанова Кабінету Міністрів України від 2016 p. URL: https:/ / www.kmu.gov.ua/npas/248941325.

Що у розвитку громад і територій відбулося за 2019 рік - дані моніторингу децентралізації. URL: https:// decentralization.gov.ua/news/12055.

Гроші мають йти за повноваженнями, а не навпаки: триває обговорення питань розмежування повноважень органів влади на місцях.14 травня 2020 р. Онлайн-обговорення за сприяння Швейцарсько-українського проєкту «Підтримка децентралізації в Україні». DESPRO. URL: https:/ / decentralization.gov.ua/news/12455.

\section{References}

Derzhavna strategiya regional'nogo rozvy'tku na period do 2027 roku (2020), https://oda.odessa.gov.ua/ statics/pages/files/5e37ef526fbf7.pdf.

Zhalilo Ya. (2018) Propry'ncy' py' suchasnoyi polity'ky' regional'nogorozvy'tku. [Elektronny'jresurs]-Rezhy'm dostupu: https:/ / dt.ua/macrolevel/pro-principi-suchasnoyi-politiki-regionalnogo-rozvitku-281358_.html.

Zakon Ukrayiny' (2020) Pro vnesennya zmin do deyaky'x zakoniv Ukrayiny' shhodo vy'znachennya tery' torij ta administraty'vny'h centriv tery'torial'ny'h gromad" 16.04.2020 Golos Ukrayiny', 79.

Zakon Ukrayiny' (2020) “Pro dobrovil'ne ob' yednannya tery'torial'ny'h gromad”, https:/ / zakon.rada.gov.ua/ laws/show/157-19.

Koncepciya rozvy'tku girs'ky'h tery'torij ukrayins'ky'h Karpat na 2019-2027 roky' (2019), https:/ / zakon.rada.gov.ua/laws/show/232-2019-\%D1\%80.

Malash S. (2017) Problematy'ka vzayemovidnosy'n mizh organamy' vy'konavchoyi vlady' ta gromads'kistyu. Derzhavne upravlinnya: teoriya ta rozvy'tok, 9, 21-27.

Ministerstvo rozvy'tku gromad ta tery'torij Ukrayiny' (2020) Monitory'ng procesu decentralizaciyi vlady' ta reformuvannya miscevogo samovryaduvannya stanom na 10 sichnya 2020, https:/ / decentralization.gov.ua/ uploads/library/file/526/10.01.2020.pdf.

Minregion (2020) Smart-specializaciya ye obov'yazkovoyu u sy'stemi strategichnogo planuvannya regional'nogo rozvy'tku, https:/ / decentralization.gov.ua/news/10590.

Postanova Kabinetu ministriv Ukrayiny” (2016) “Pro zatverdzhennya Ty'povogo polozhennya pro agenciyu regional'nogo rozvy'tku", https://www.kmu.gov.ua/npas/248941325.

Shho u rozvy'tku gromad i tery'torij vidbulosya za 2019 rik - dani monitory'ngu decentralizaciyi, https:/ / decentralization.gov.ua/news/12055.

Groshi mayut' jty' za povnovazhennyamy', a ne navpaky': try'vaye obgovorennya py'tan' rozmezhuvannya povnovazhen' organiv vlady' na miscyax (14.05.2020). Onlajn-obgovorennya za spry'yannya Shvejczars'koukrayins'kogo proektu “Pidtry'mka decentralizaciyi v Ukrayini” DESPRO. https://np.pl.ua/2020/05.

\section{Анотація}

Пехник А. В., Кройтор А. В. Реформи місцевого самоврядування та територіальної організації влади в Україні в контексті становлення громадянського суспільства. - Стаття.

У статті розглянуто аспекти ефективності місцевого самоврядування та територіальної організації влади в Україні в контексті розвитку громадянського суспільства як невід'ємного елемента процесу демократизації політичної системи держави. Зокрема, проаналізовано сучасний стан та визначено перспективи розвитку регіональної політики в Україні крізь призму реформування місцевого самоврядування, що не лише забезпечить економічну самодостатність місцевих громад, а й дозволить їм стати сучасним механізмом формування місцевих еліт та лідерів, незалежних у своїй діяльності від регіональних та національних; розглянуті питання оцінювання основних чинників, що впливають на 
ефективність діяльності регіональних та місцевих органів влади. Підкреслюється, що органам місцевого самоврядування завжди необхідно проводити аналіз якості й ефективності своєї діяльності; визначати, чому реальне виконання виявляється гірше очікуваних результатів або перевищує встановлені раніше очікувані результати виконання. Крім того, у статті зазначено, що реформування місцевого самоврядування повинно забезпечити підвищення якості життя громадян через створення умов сталого розвитку громад. Ефективне реформування регіональної політики держави дозволить зменшити ідеолого-політичне протистояння еліт та використання у виборчих кампаніях як регіонального, так і місцевого рівнів історичних, мовних гасел як вдалої маніпулятивної виборчої технології. Гальмом у вирішенні проблеми дисбалансу регіонального розвитку впродовж декількох років було небажання колишнього керівництва держави відмовлятися від ручного управління регіонами. Збереження непрозорості й суб' єктивності в ухваленні рішень щодо регіонального розвитку давало змогу вищим посадовим особам держави необмежено впливати на керівників регіональних і місцевих органів влади.

Ключовi слова: регіональна влада, місцева влада, децентралізація, місцеве самоврядування.

\section{Summary}

Pekhnik A. V., Kroytor A. V. Reform of the government's self-determination and territorial organization of power in Ukraine in the context of the emergence of a huge suspension. - Article.

The article considers aspects of the effectiveness of local self-government and territorial organization of power in Ukraine in the context of the development of civil society as an integral element of the process of democratization of the political system of the state. In particular, the current state and prospects of regional policy development in Ukraine through the prism of local government reform, which will not only ensure the economic self-sufficiency of local communities, but also allow them to become a modern mechanism for forming local elites and leaders independent of regional and national; the issues of assessment of the main factors influencing the efficiency of regional and local authorities are considered. It is emphasized that local governments always need to analyze the quality and effectiveness of their activities; determine why the actual performance is worse than the expected results or exceeds the previously set expected performance results. In addition, the article states that the reform of local self-government should improve the quality of life of citizens by creating conditions for sustainable development of communities. Effective reform of the regional policy of the state will reduce the ideological and political confrontation of elites and the use in election campaigns of both regional and local levels of historical, broadcaster slogans as a successful manipulative election technology. The brake in resolving the problem of regional development imbalance for a number of years was the reluctance of the former state leadership to abandon manual management of the regions. Maintaining non-transparency and subjectivity in regional development decisions has allowed senior government officials to exert unlimited influence on the heads of regional and local authorities.

Key words: regional government, local government, decentralization, local self-government. 